\title{
Proteomic detection of a large amount of SCGF $\alpha$ in the stroma of GISTs after imatinib therapy
}

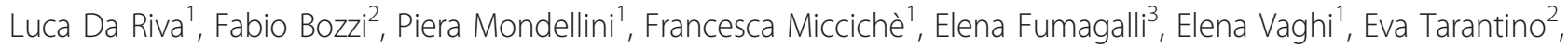
Veronica Huber ${ }^{4}$, Alessandro Gronchi ${ }^{5}$, Elena Tamborini ${ }^{2}$, Marco A Pierotti ${ }^{6}$, Silvana Pilotti ${ }^{2}$ and Italia Bongarzone $^{1^{*}}$

\begin{abstract}
Background: Gastrointestinal stromal tumors (GISTS) are the most frequent mesenchymal tumors to develop in the digestive tract. These tumors are highly resistant to conventional chemotherapy and only the introduction of imatinib mesylate has improved the prognosis of patients. However, Response Evaluation Criteria in Solid Tumors are inappropriate for assessing tumor response, and the histological/pathological response to imatinib is variable, heterogeneous, and does not associate with clinical response. The effects of imatinib on responding GISTs are still being explored, and few studies correlate the clinical response with the histological response after pharmacological treatment. Recently, apoptosis and autophagy were suggested as possible alternative mechanisms of pharmacological response.
\end{abstract}

Methods: Here, we used a proteomic approach, combined with other analyses, to identify some molecular stromal components related to the response/behavior of resected, high-risk GISTs after neoadiuvant imatinib therapy.

Results: Our proteomic results indicate an elevated concentration of Stem Cell Growth Factor (SCGF), a hematopoietic growth factor having a role in the development of erythroid and myeloid progenitors, in imatinibresponsive tumor areas. SCGF $\alpha$ expression was detected by mass spectrometry, immunohistochemistry and/or western blot and attributed to acellular matrix of areas scored negative for KIT (CD117). RT-PCR results indicated that GIST samples did not express SCGF transcripts. The recently reported demonstration by Gundacker et al. [1] of the secretion of SCGF in mature pro-inflammatory dendritic cells would indicate a potential importance of SCGF in tissue inflammatory response. Accordingly, inflammatory infiltrates were detected in imatinib-affected areas and the CD68-positivity of the SCGF-positive and KIT-negative areas suggested previous infiltration of monocytes/ macrophages into these regions. Thus, chronic inflammation subsequent to imatinib treatment may determine monocyte/macrophage recruitment in imatinib-damaged areas; these areas also feature prominent tumor-cell loss that is replaced by dense hyalinization and fibrosis.

Conclusions: Our studies highlight a possible role of SCGF $\alpha$ in imatinib-induced changes of GIST structure, consistent with a therapeutic response.

\section{Background}

Gastrointestinal stromal tumors (GISTs) are the most frequent mesenchymal tumors to develop in the digestive tract. They typically arise from the stomach (40-70\%) or small intestine (20-40\%) but can also occur in the colonrectum (10-15\%) and rarely in the esophagus. At least $10-30 \%$ of tumors are discovered incidentally during

\footnotetext{
* Correspondence: italia.bongarzone@istitutotumori.mi.it

${ }^{1}$ Proteomics Laboratory, Department of Experimental Oncology and Molecular Medicine, Fondazione IRCCS Istituto Nazionale dei Tumori, Milan, Italy

Full list of author information is available at the end of the article
}

laparotomy, endoscopy, or other imaging studies; 15-47\% of patients present with overt metastatic disease and common sites of metastases include liver, peritoneum, and omentum [2-4]. GISTs are thought to originate from the interstitial cells of Cajal or their precursor cells [5]. Most GISTs are characterized by gain-of-function mutations in the genes encoding $K I T$ and platelet-derived growth factor receptor alpha (PDGFRA) [6], mutations that appear to be mutually exclusive. The emerging role of stem cell factor (SCF) as the ligand of the receptor tyrosine kinase KIT [7-9] suggests that an autocrineparacrine loop serves as a possible further mechanism of

\section{() Biomed Central}


action [10]. However, the SCF/KIT system plays an important role not only in the differentiation and proliferation of interstitial cells of Cajal and the development of GISTs but also in the development of hematopoietic cells such as mast cells, erythroblasts, and melanocytes [11].

GISTs are highly resistant to conventional chemotherapy [12]; in the past decade, the introduction of imatinib mesylate (Gleevec ${ }^{\circledR}$, Novartis Pharmaceutical Corporation, NJ, USA), a KIT receptor blocker, has significantly improved the prognosis of GIST patients. Tumor response depends on the presence/absence and type of mutations in KIT or PDGFR. Unfortunately, the major problem with imatinib treatment is resistance, mainly secondary resistance that generally evolves in most patients after a median of two years of therapy $[13,14]$.

Eighty to eighty-five percent of patients with advanced GISTs exhibit an initial benefit from imatinib treatment; however, the response level varies from rapid and gross reduction in tumor volume to little or no tumor shrinkage (described as stable disease) [6]. Size-based response criteria such as the World Health Organization criteria or the current international Response Evaluation Criteria in Solid Tumors are thus thought to underestimate the response and are not appropriate tools to assess tumor response to imatinib [15]. Consequently, the clinical management of these patients and the criteria used to assess clinical response to imatinib therapy have recently been redefined [16]. In accordance with previously reported criteria, GISTs can be classified using the following scores: high responders, 0 to $<50 \%$ residual viable tumor cells with no mitosis, and no obvious Ki-67 immunostaining; moderate responders, $>50 \%$ to $90 \%$ tumor cells, no mitosis, and Ki-67 immunostaining in 0 to $<10 \%$ of cells; low responders, $>50 \%$ to $90 \%$ tumor cells, mitotic index $>10 / 50$ high-power fields, Ki-67 immunostaining in $20-30 \%$ or $>30 \%$ of cells; and non-responders, $>90 \%$ tumor cells $[17,18]$.

The histological/pathological response of GIST to imatinib therapy is also variable and heterogeneous from nodule to nodule within the same resection, as well as within the same lesion, and does not correlate well with clinical response. Limited studies of the histopathological changes in imatinib-treated patients indicate a significant change in the appearance of the tumor tissue following preoperative systemic imatinib therapy in GISTs; alterations particularly occur in the stromal compartment and are visible during standard pathological assessment. The density of the tumor and the number of intratumoral vessels decrease significantly and areas of cystification and hemorrhage are clearly visible. Tumors become homogeneous and hypodense. However, even in highly responsive tumors, microscopic foci of viable cells are seen either as isolated tumor cells or as distinct micronodules embedded in an extensively hyalinized background.

The molecular effects of imatinib on responding GISTs are currently being explored. Apoptosis (programmed cell death type I) has been frequently described in GIST cell lines treated with imatinib mesylate $[19,20]$; importantly, McAuliffe et al. [21] indicate that the action of imatinib may be both cytotoxic (by evidence of apoptosis) and cytostatic. Recently, autophagy (programmed cell death type II) has been suggested as a possible alternative mechanism of response to the imatinib mesylate treatment in clinical biopsies [22]. Autophagy is the major self-degradative process in eukaryotic cells and has multiple physiological functions, including protein degradation, organelle turnover, and response of cancer cells to chemotherapy [23].

In this report, we used a proteomic approach in combination with other analyses to investigate the protein composition of highly responsive, resected GISTs after imatinib mesylated neoadjuvant therapy. Our aim was to identify several molecular components of the stroma with expression patterns possibly related to tumor response/behavior.

\section{Methods}

\section{Patients and materials}

GIST diagnosis was previously performed according to currently accepted criteria and confirmed by molecular analysis demonstrating activating mutations in the KIT receptor [24]. Tumor characteristics and treatment are detailed in Table 1. A tumor tissue sample (GIST 1) from an untreated patient was included in the analysis. Specimens from each patient, verified by histopathology, were snap-frozen in liquid nitrogen and stored in cryotubes in liquid nitrogen. The specimens (one sample per case) were assessed for response to imatinib mesylate treatment based on the morphological criterion of residual cellularity. Written informed consent to participate in the study was obtained from each patient before surgery in accordance with the ethical guidelines of our institute. Plasma samples were collected under a protocol approved by our institutional review board and the donors provided written informed consent.

\section{Protein extraction}

Tumor specimens were pulverized in a Mikro-Dismembrator II (B. Braun Biotech International, Melsungen, Germany). The pulverized tissue samples and the cell pellets from cell culture were recovered in ice-cold buffer containing $50 \mathrm{mM}$ HEPES (pH 7.6), $150 \mathrm{mM} \mathrm{NaCl}, 10 \%$ glycerol, $1 \%$ Triton X-100, $1.5 \mathrm{mM} \mathrm{MgCl}_{2}, 1 \mathrm{mM}$ EGTA, $10 \mathrm{mM} \mathrm{Na}_{4} \mathrm{P}_{2} \mathrm{O}_{7}, 100 \mathrm{mM} \mathrm{NaF}, 1 \mathrm{mM}$ PMSF, $1 \mathrm{mM}$ sodium orthovanadate, and Complete Mini protease inhibitors cocktail (Roche, Milan, Italy) according to the manufacturer's instructions. After 30 min incubation with 
Table 1 Clinical, pathological and molecular characterists of GISTs

\begin{tabular}{|c|c|c|c|c|c|c|}
\hline Case & $\begin{array}{l}\text { Anatomical } \\
\text { location }\end{array}$ & Molecular Status & $\begin{array}{l}\text { Clinical } \\
\text { response }\end{array}$ & Pathological response $^{2}$ & $\begin{array}{l}\text { Tumor } \\
\text { Sample }\end{array}$ & $\begin{array}{l}S_{\text {Size }}^{3} \\
(\mathrm{~cm})\end{array}$ \\
\hline GIST 1 & Stomach & KIT exon 11 Del 558-563 & Non treated & Non treated & Primary & $>10$ \\
\hline GIST 2 & Ileum & KIT exon 11 L576P & Stable disease & $>90 \%$ of viable cells-non responder & Recurrence & $2-5$ \\
\hline GIST 3 & Esophagus & KIT exon 11 Del 554-558 & In response & $10 \%$ of viable cells-high responder & Primary & $5-10$ \\
\hline GIST 4 & Stomach & KIT exon 11 Del 557-558 & In response & $10 \%$ of viable cells-high responder & Primary & $>10$ \\
\hline GIST 5 & Stomach & KIT exon 11 V559D & In response & $10 \%$ of viable cells-high responder & Primary & $>10$ \\
\hline GIST6 & Stomach & PDGRF alpha D842V & Unresponsive & $25 \%$ of viable cells-high responder & Recurrence & $<2$ \\
\hline GIST7 & Ileum & KIT exon 9 Dup 502-503 & Unresponsive & $>90 \%$ of viable cells-non responder & $\begin{array}{c}\text { Liver } \\
\text { metastasis }\end{array}$ & $5-10$ \\
\hline GIST8 & Pelvis & $\begin{array}{c}\text { KIT exon } 11 \text { Del 558-560 and } \\
\text { V557C }\end{array}$ & Unresponsive & $>5 \%$ of viable cells-high responder & $\begin{array}{c}\text { Liver } \\
\text { metastasis }\end{array}$ & $2-5$ \\
\hline GIST9 & Stomach & PDGFR alpha D842V & Unresponsive & $>90 \%$ of viable cells-non responder & Primary & $2-5$ \\
\hline GIST10 & Stomach & KIT wt & Unresponsive & $>90 \%$ of viable cells-non responder & Primary & $>10$ \\
\hline GIST11 & Stomach & KIT Dup P577-K581 & Unresponsive & $>90 \%$ of viable cells-non responder & Primary & $5-10$ \\
\hline GIST12 & Omentum & KIT Dup A502-Y503 and N822K & Unresponsive & $>90 \%$ of viable cells-non responder & Metastasis & $<2$ \\
\hline GIST13 & Intestin & KIT K642E and N822K & Unresponsive & $>90 \%$ of viable cells-non responder & Primary & $>10$ \\
\hline GIST14 & Intestin & KIT Del M552-Y553 and E554K & In response & $\begin{array}{l}\text { 50-90\% of viable cells-moderate } \\
\text { responder }\end{array}$ & Recurrence & $5-10$ \\
\hline GIST15 & Stomach & KIT K642E & In response & $\begin{array}{l}\text { 50-90\% of viable cells-moderate } \\
\text { responder }\end{array}$ & Metastasis & $5-10$ \\
\hline GIST16 & Intestin & KIT Dup 502-503 & In response & $\begin{array}{l}\text { 50-90\% of viable cells-moderate } \\
\text { responder }\end{array}$ & Primary & $<2$ \\
\hline
\end{tabular}

${ }^{1}$ Evaluated on the frozen material used for the proteomic/biochemical analyses [16].

${ }^{2}$ According to refs 17 and 18 .

${ }^{3}$ The size of the tumor was measured considering the maximum diameter.

gentle rocking at $4^{\circ} \mathrm{C}$, lysates were cleared by centrifugation for $20 \mathrm{~min}$ at $13,000 \mathrm{rpm}$. Supernatants were collected and protein quantification was performed with the BCA ${ }^{\mathrm{TM}}$ Protein Assay Kit (Thermo Scientific, Milan, Italy) according to the manufacturer's instructions.

\section{One-dimensional SDS-PAGE}

Thirty micrograms of total extract from GIST samples and of plasma were loaded on one-dimensional 4-12\% NuPAGE ${ }^{\circledR}$ precast gels (Invitrogen, Milan, Italy). Proteins were visualized with G250 Coomassie Blue (Bio-Rad, Milan, Italy) by standard procedures.

In-gel tryptic digestion, matrix-assisted laser desorption/ ionization-time of flight-mass spectrometry (MALDI-TOFMS), and peptide mass fingerprinting

For protein profiling, protein bands were excised from Coomassie-stained preparative gels and processed as previously described [25]. MALDI-TOF-MS was carried out using a Voyager-DE STR (Applied Biosystems, Milan, Italy), equipped with a nitrogen laser $(337 \mathrm{~nm})$.

Monoisotopic peptide masses were analyzed using the Aldente software http://www.expasy.org/tools/. Input was searched according to: Aldente, UniProtKB/SwissProt; predefined taxon, Mammalia; Spectrometer internal error max, 25. Only proteins identified in at least three separate experiments were considered.

\section{OFFGEL protein fractionation}

A preparative-scale OFFGEL was used for isoelectric focusing of proteins. To perform protein fractionation according to isoelectric point, the 3100 OFFGEL Fractionator and the OFFGEL Kit 3-10 (Agilent Technologies, Milan, Italy) were used following the manufacturer's instructions [26]. The device was set up for the 24-fraction separation using the $24 \mathrm{~cm}$-long IPG gel strip with a linear $\mathrm{pH}$ gradient from 3 to 10 . The proteins were separated in a two-phase system consisting of a liquid upper phase (focusing buffer provided by the supplier) separated in wells and a lower IPG gel strip phase. The sample was focused using the recommended method for 24-well OFFGEL fractionation with a maximum current of $50 \mu \mathrm{A}$. The separation method consisted of a cooling platform temperature of $15^{\circ} \mathrm{C}$ with electrical setting parameters of 8,000 $\mathrm{V} / \mathrm{h}, 100,000 \mathrm{~V}, 200 \mathrm{~W}$, and $50 \mu \mathrm{A} /$ strip. The focusing was stopped after the total voltage reached $64 \mathrm{kVh}$. After focusing, samples were recovered from each well and transferred to individual microtubes. Corresponding protein fractions were purified with the 2-D Clean Up (GE Healthcare, Milan, Italy) and the protein pellets were 
dissolved in running sample buffer compatible with onedimensional SDS-PAGE. For protein profiling, protein bands were excised from Coomassie-stained preparative gels and processed as previously described [25].

\section{Cell culture}

The human papillary thyroid carcinoma cell line, TPC1, was grown adherently in Dulbecco's Modified Eagle's Medium (Gibco, Milan, Italy) supplemented with 10\% fetal bovine serum HyClone (Celbio, Milan, Italy) and $1 \mathrm{mM}$ sodium pyruvate (Lonza, Milan, Italy). Human Embryonic Kidney (HEK) 293T (ATCC number CRL1573) cells were grown adherently in Dulbecco's Modified Eagle's Medium supplemented with 10\% fetal bovine serum and L-glutamine (Lonza).

\section{Conditioned medium concentration}

An equal volume $(\sim 5 \mathrm{ml})$ of conditioned medium for each sample (mock and transfected cells) was loaded into a spin concentrator (Agilent Technologies) with a $5 \mathrm{kDa}$ molecular weight cut-off and centrifuged at $4,000 \mathrm{rpm}$ and $10^{\circ} \mathrm{C}$ until samples were concentrated to a final volume of $150-200 \mu$ l. Protein concentration was determined by BCA assay.

\section{Western blot}

An equal amount of protein for each sample $(30 \mu \mathrm{g})$ was loaded on a one-dimensional 4-12\% NuPAGE ${ }^{\mathbb{B}}$ precast gel (Invitrogen). Proteins were transferred in NuPAGE $^{\circledR}$ transfer buffer (Invitrogen) and 20\% ethanol onto a nitrocellulose membrane (Hybond ${ }^{\mathrm{TM}}-\mathrm{C}$ Super, Amersham Biosciences, Milan, Italy) and checked for equal sample loading by Red Ponceau S (Sigma-Aldrich, Milan, Italy) staining. Blots were blocked for $1 \mathrm{~h}$ with TBS (10 mM Tris- $\mathrm{HCl}$ [pH 7.5], $150 \mathrm{mM} \mathrm{NaCl}$ ) plus $0.1 \%$ Tween 20 (TBS-T buffer) containing $1 \%$ bovine serum albumin (Sigma-Aldrich) and 3\% ovalbumin (Sigma-Aldrich), then hybridized in the same buffer with specific antibodies at $4^{\circ} \mathrm{C}$ overnight using the recommended dilutions. After incubation, the blots were washed in TBS-T buffer and incubated for $1 \mathrm{~h}$ at room temperature in previously described buffer using appropriate secondary antibodies (1:4,000). After incubation, the blots were washed in TBS-T buffer, and immunoreactive proteins were visualized using an enhanced ECL system (ECL ${ }^{\circledR}$ Western blotting detection reagents, GE Healthcare Life Sciences, Milan, Italy) according to the manufacturer's protocol. Monoclonal mouse anti-human SCGF/CLEC11a antibody was supplied by R\&D Systems (Milan, Italy). The ECL ${ }^{\circledR}$ antimouse IgG, horseradish peroxidase-linked whole antibody from sheep was obtained from GE Healthcare Life Sciences.

\section{Immunohistochemistry}

Immunohistochemistry was performed on $2-\mu \mathrm{m}$ formalinfixed and paraffin-embedded sections of representative tumoral areas deparaffined in xylene and rehydrated in graded alcohols. Endogenous peroxidase activity was blocked by treatment for 10 min with $0.3 \%$ hydrogen peroxide in distilled water. Antigen retrieval was obtained by autoclaving for $15 \mathrm{~min}$.

The slides were cooled under tap water, washed three times in $0.05 \mathrm{M}$ phosphate-buffered saline plus $0.1 \%$ Triton, and incubated with ultra v-block (Lab Vision Corp, Newmarker, UK) for $10 \mathrm{~min}$ at room temperature. Then, they were incubated at room temperature for $1 \mathrm{~h}$ with the monoclonal mouse anti-human SCGF/CLEC11a antibody (R\&D Systems) diluted 1:400 in citrate buffer (pH 6). The slides were washed again three times in 0.05 $\mathrm{M}$ phosphate-buffered saline plus $0.1 \%$ Triton and developed using the Ultra Vision LP Volume Detection System (Lab Vision Corp). After washes in $0.05 \mathrm{M}$ phosphate-buffered saline, peroxidase activity was detected with diaminobenzidine for $10 \mathrm{~min}$ in the dark. The slides were counterstained with hematoxylin. Immunohistochemical analysis for KIT was performed using an antibody against CD117, as previously described [27]. Positivity was defined as the detection of immunopositivity in $>90 \%$ of cells.

\section{Plasmid construction}

Total RNA of the TPC1 cell line was prepared using a TRIZOL reagent (Life Technologies, Italy), the oligo(dT)primed cDNA was synthesized using a RT-PCR kit (Stratagene, Milan, Italy). Oligonucleotides 5'-CCAAGCTTTCCAGCTTAATGCAG-3'(forward) and 5'-TAAAGCGGC CGCCCCGCTAGAA-3'(reverse) were used in PCR to amplify the full human SCGF- $\alpha$ (hSCGF- $\alpha$, UniProt accession number Q9Y240) sequence. Taq Phusion ${ }^{\circledR}$ High Fidelity DNA polymerase (Finnzymes, Espoo, Finland) was used with the following thermal cycling conditions: initial denaturation at $98^{\circ} \mathrm{C}$ for $30 \mathrm{sec} ; 35$ cycles of denaturation at $98^{\circ} \mathrm{C}$ for $10 \mathrm{sec}$, annealing at $60^{\circ} \mathrm{C}$ for $30 \mathrm{sec}$, extension at $72^{\circ} \mathrm{C}$ for $40 \mathrm{sec}$; and final extension at $72^{\circ} \mathrm{C}$ for $7 \mathrm{~min}$. The hSCGF- $\alpha$ cDNA was subcloned into the pcDNA3.1 plasmid vector (Invitrogen). The plasmid expressing hSCGF- $\beta$ was obtained by mutagenesis of the plasmid expressing hSCGF- $\alpha$ using the Quick-Change ${ }^{\circledR}$ II XL SiteDirected Mutagenesis Kit (Stratagene, Milan, Italy), according to the manufacturer's protocol. The DNA sequences contained in both vectors were checked by automatic sequencing.

\section{Cell transfection}

HEK 293T cells were transiently transfected by calcium phosphate precipitation, as previously described [28], with the pcDNA3 expression vector (Invitrogen) alone 
(mock) or with the plasmid carrying the insert for SCGF- $\beta$.

\section{Removal of O-linked oligosaccharides from SCGF}

Suitable amounts (based on western blotting with antiSCGF) of cell and tissue protein extracts and secreted proteins were incubated at $37^{\circ} \mathrm{C}$ for $4 \mathrm{~h}$ with $\mathrm{O}$-glycosidase (Sigma-Aldrich) and $\alpha(2 \rightarrow 3,6,8,9)$ neuraminidase (sialidase, Sigma-Aldrich) according to the manufacturer's protocol. The digested samples were analyzed by western blotting with anti-SCGF.

\section{Results}

To explore the protein expression pattern of GIST samples treated with imatinib mesylate, protein extracts from five GISTs were loaded onto one-dimensional SDS-PAGE and visualized by Coomassie staining. These five samples consisted of one untreated tumor (GIST 1), three tumors from high-responder patients (GISTs 3-5), and one tumor (GIST 2) from a patient with clinically stable disease but who was scored as a non-responder (Table 1). The protein patterns of the highly responsive tumors (Figure 1, lanes C-E) were uniform and contained fewer protein bands than the other samples (Figure 1, lanes A and B). The staining patterns of the GIST samples did not differ consistently from that of a pool of plasma samples from healthy donors (Figure 1, lane F). MS of gel bands obtained after OFFGEL fractionation of the extracts (data not shown) confirmed that the majority of proteins were blood components (Table 2).

In the GIST 5 extract, Coomassie staining revealed bands (bands 8-10 in Figure 1A, lane E, and Figure 1B) that were not present in the plasma sample. Bands 8 and 9 corresponded to SCGF, also known as C-type lectin domain family member 11A (CLEC11A), an important hematopoietic growth factor with burst-promoting activity for human bone marrow erythroid progenitors [29]. Band 10 corresponded to $\mathrm{C} 1 \mathrm{q}$, the initiator of the classical complement cascade [30].

Western blotting with anti-SCGF antibody confirmed the presence of SCGF-positive bands in GIST 5 extract $(b$ and $c$ in Figure 2, lane B) and highlighted the presence of a third isoform of $\sim 46 \mathrm{kDa}$ ( $a$ in Figure 2, lane B) that was not detected by the proteomic analysis. All three isoforms were undetectable in a plasma sample (Figure 2, lane C), consistent with the observation that the SCGF plasma concentration was too low to be analyzed by western blot. In the peripheral blood of adults, SCGF concentration can only be detected by enzyme-linked immunosorbent assay because the concentration is approximately $10-20 \mathrm{ng} / \mathrm{ml}$ [31]. Using Coomassie staining to visualize the electrophoresed SCGF proteins, we estimated at least $60 \mathrm{ng}$ of protein in the GIST 5 sample. Since $30 \mu \mathrm{g}$ of tissue extract was analyzed, we calculated the SCGF concentration to be $0.5 \mathrm{ng} / \mu \mathrm{g}$ in the GIST extract, which was much more protein than would be present in an equivalent amount of plasma protein $(0.03-2 \mathrm{pg} / \mu \mathrm{g})$.

To assess the possible origin and localization of SCGF, we performed immunohistochemistry on all five GIST samples. GIST 5 (Figure 3B) displayed a strong SCGF positivity, consistent with the western blot, that was restricted to the stroma compartment. The rare viable tumoral cells present in the responding area were negative in the cytoplasm and the nucleus. However, these cells retained weak cytoplasmic KIT reactivity (Figure 3C). The responding cases (GISTs 3 and 4) and the naïve GIST (GIST 1) were negative (Additional file 1 and data not shown). Interestingly, GIST 2 (Figure 3D-F) exhibited minimal areas of regression that were mostly depleted of tumoral cells and were SCGF-positive and KIT-negative. RT-PCR did not reveal the presence of SCGF transcripts in responding or non-responding GISTs (Additional file 2), corroborating the hypothesis that blood is likely the source of SCGF.

SCGF is a largely uncharacterized hematopoietic mediator that promotes enhanced erythroid progenitor formation from human bone marrow [32]. Stem cell transplantationelevated serum SCGF levels are associated with enhanced hematopoietic recovery [32], and the differentiation of dendritic cells in mature type I inflammatory cells is accompanied by an increase in SCGF secretion [1]. Based on these observations, we hypothesized that an inflammatory reaction induced by imatinib treatment could be responsible for the SCGF positivity we observed in our GIST specimens. We therefore employed immunohistochemistry to investigate the presence of macrophage/dendritic cells using anti-CD68 antibodies in samples GIST 2 and 5. Interestingly, we observed areas of CD68 positivity in GIST 5, while GIST 2 presented a diffuse infiltration of CD68-positive macrophages. In both cases the corresponding stromal counterpart was SCGF-positive (Figure 4).

In order to test the consistency of the relationship between SCGF expression and the histological response to imatinib, we analyzed SCGF expression in tumor areas scored as acellular or with $<10 \%$ residual tumoral cells and in those areas scored as non-responsive or scarcely responsive in three imatinib-treated patients (GISTs 6, 7 and 8 in Table 1). Figure 5A summarizes the results obtained in a comparative analysis of non-affected and affected tumor areas: the hematoxylin-eosin staining of the histological sections (panels 1-3; 6-8; and 11-13); the images of the protein lysates prepared from adjacent tumor areas that were separated onto SDS gels and stained with Coomassie-blu (panels 4, 9 and 14); and, the western blotting of the same protein lysates probed by with anti-SCGF antibody (panels 5, 10 and 15). Lysates from imatinib-affected areas displayed a simplified protein band profile; notably, the anti-SCGF antibody recognized an SCGF-related band in protein lysates from 


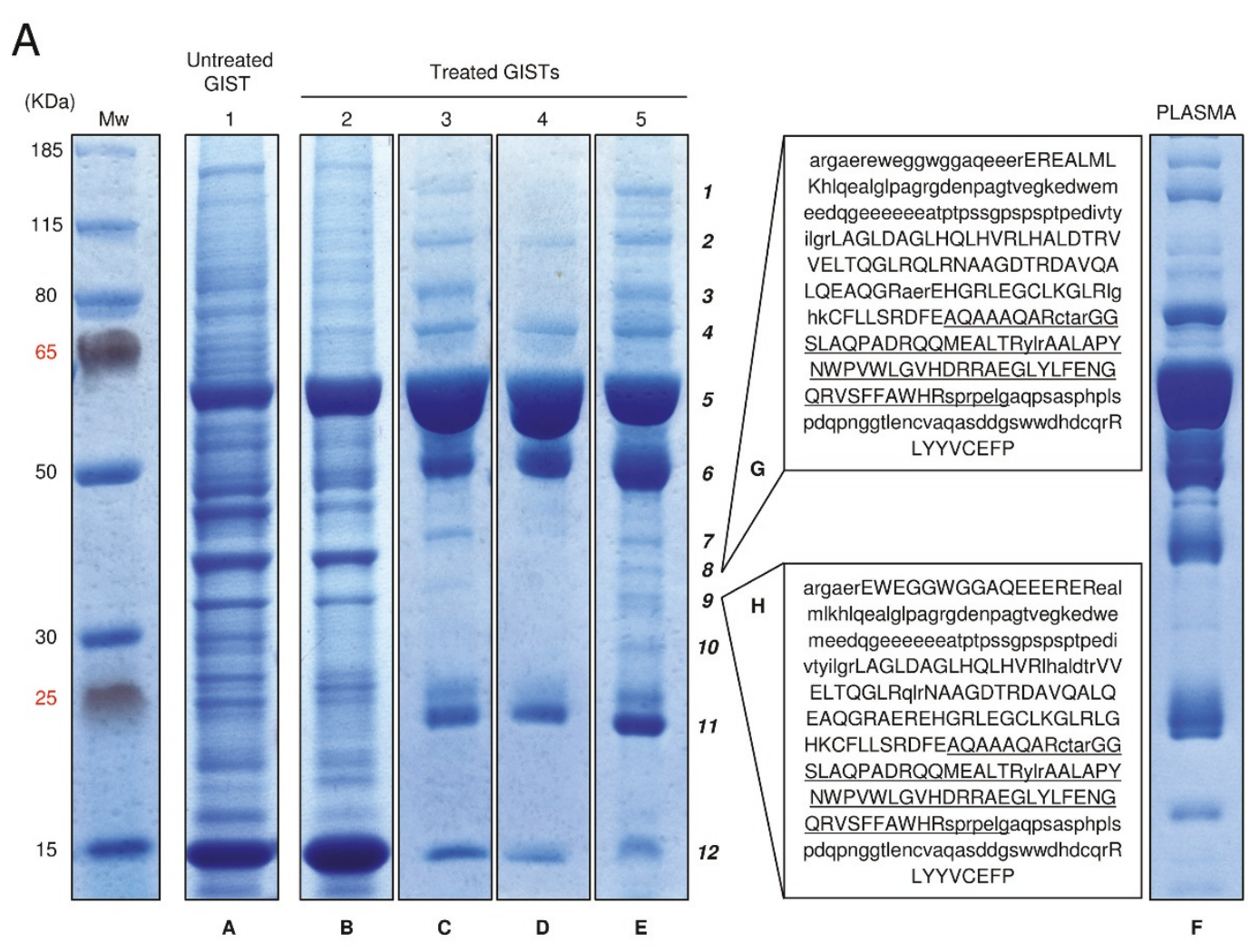

B

$\begin{array}{cc}\text { Band no. }{ }^{1} & \mathrm{AC}^{2} \\ \mathbf{1} & \mathrm{P} 08603 \\ \mathbf{2} & \mathrm{P} 01024 \\ \mathbf{3} & \mathrm{P} 01857 \\ \mathbf{4} & \mathrm{P} 02787 \\ \mathbf{5} & \mathrm{P} 02768 \\ \mathbf{6} & \mathrm{P} 01857 \\ \mathbf{7} & \mathrm{P} 60709 \\ \mathbf{8} & \mathrm{Q} 9 \mathrm{Y} 240 \\ \mathbf{9} & \mathrm{Q} 9 \mathrm{Y} 240 \\ \mathbf{1 0} & \mathrm{P} 02746 \\ \mathbf{1 1} & \mathrm{P} 02647 \\ \mathbf{1 2} & \mathrm{P} 68871\end{array}$

$\begin{array}{cc}\mathrm{DE}^{3} & \mathrm{Mw}{ }^{4} \\ \text { Complement factor H } & 137 \\ \text { Complement C3 } & 185 \\ \text { Ig gamma-1 chain C region } & 36 \\ \text { Serotransferrin } & 75 \\ \text { Serum albumin } & 66 \\ \text { Ig gamma-1 chain C region } & 36 \\ \text { Actin, cytoplasmic } & 42 \\ \text { Stem cell growth factor } & 34 \\ \text { Stem cell growth factor } & 34 \\ \text { Complement C1q subcomponent subunit B } & 24 \\ \text { Apolipoprotein A-I } & 28 \\ \text { Hemoglobin subunit beta } & 16\end{array}$

Figure 1 Protein expression in GISTs from patients treated with imatinib mesylate. A) SDS-PAGE (4-12\% bis-Tris gel) of total protein extracts from three highly responsive GIST patients (lanes C-E) and from one poorly responsive patient with stable disease (lane B). A tumor tissue sample from an untreated GIST patient is shown as the control (lane A). A pool of plasma samples from healthy subjects (lane F) is shown for comparison with GIST extracts. Lanes G and H demonstrate the protein coverage of SCGF isoforms assessed by MALDI-TOF-MS of tryptic peptides obtained from digestion of the proteins in bands 8 and 9, respectively. The boxed sequences correspond to the sequence without signal peptide (amino acids 1-21) of SCGF- $\alpha$ (Q9Y240) that is available in the Aldente (ExPASy Proteomics Server) database. Capital letters indicate the sequence detected by MS, while the underlined sequence indicates the 78 amino acids that are lacking in the $\beta$-form. Bold numbers denote the proteins identified by MS and listed in panel B. B) Proteins identified in GIST 5 (lane E) after SDS-PAGE fractionation, tryptic digest, and MALDI-TOF-MS. ${ }^{1}$ Number refers to the specific band position on the SDS-PAGE in Figure 1A, lane E. ${ }^{2}$ Swiss-Prot/TrEMBL accession line. ${ }^{3}$ Swiss-Prot/TrEMBL description line. ${ }^{4}$ Theoretical protein mass. 
Table 2 List of proteins identified after OFFGEL and SDSPAGE fractionation, tryptic digest, and MALDI-TOF MS analysis

\begin{tabular}{|c|c|c|c|c|c|}
\hline No. & $\underline{A C}^{1}$ & $\underline{\mathrm{DE}}^{2}$ & $\mathrm{Mw}^{3}$ & $\underline{\mathrm{pl}}^{4}$ & $\mathrm{Cov}^{5}$ \\
\hline 1 & $\underline{\mathrm{P} 01009}$ & Alpha-1-antitrypsin & 44 & 5.4 & 47 \\
\hline 2 & $\underline{\mathrm{P} 04217}$ & Alpha-1B-glycoprotein & 52 & 5.6 & 38 \\
\hline 3 & $\underline{\mathrm{P} 02750}$ & Leucine-rich alpha-2-glycoprotein & 34 & 5.7 & 22 \\
\hline 4 & $\underline{\mathrm{P} 01023}$ & Alpha-2-macroglobulin & 161 & 5.9 & 28 \\
\hline 5 & $\underline{P 01011}$ & Alpha-1-antichymotrypsin & 45 & 5.3 & 32 \\
\hline 6 & $\underline{P 60709}$ & Actin, cytoplasmic 1 & 42 & 5.3 & 65 \\
\hline 7 & $\underline{P 63261}$ & Actin, cytoplasmic 2 & 42 & 5.3 & 65 \\
\hline 8 & $\underline{\mathrm{P} 43652}$ & Afamin & 67 & 5.6 & 42 \\
\hline 9 & $\underline{\mathrm{P} 02768}$ & Serum albumin & 66 & 5.7 & 66 \\
\hline 10 & $\underline{\mathrm{P} 01008}$ & Antithrombin-III & 49 & 6.0 & 30 \\
\hline 11 & $\underline{\mathrm{P} 08758}$ & Annexin A5 & 36 & 4.9 & 69 \\
\hline 12 & $\underline{\mathrm{P} 02647}$ & Apolipoprotein A-I & 28 & 5.3 & 74 \\
\hline 13 & $\underline{\mathrm{P} 06727}$ & Apolipoprotein A-IV & 43 & 5.2 & 43 \\
\hline 14 & $\underline{P 00450}$ & Ceruloplasmin & 120 & 5.4 & 15 \\
\hline 15 & $\underline{\mathrm{P} 00751}$ & Complement factor B & 83 & 6.7 & 36 \\
\hline 16 & $\underline{\mathrm{P} 08603}$ & Complement factor $\mathrm{H}$ & 137 & 6.1 & 46 \\
\hline 17 & $\underline{\mathrm{P} 01024}$ & Complement C3 & 185 & 6.0 & 11 \\
\hline 18 & $\underline{\text { POCOL4 }}$ & Complement C4b-A & 84 & 5.3 & 21 \\
\hline 19 & $\underline{\text { POCOL5 }}$ & Complement C4b-B & 84 & 5.4 & 21 \\
\hline 20 & $\underline{\mathrm{P} 02765}$ & Alpha-2-HS-glycoprotein chain A & 30 & 4.5 & 32 \\
\hline 21 & $\underline{\mathrm{P} 02679}$ & Fibrinogen gamma chain & 48 & 5.2 & 33 \\
\hline 22 & $\underline{\mathrm{P} 02792}$ & Ferritin light chain & 20 & 5.5 & 45 \\
\hline 23 & $\underline{P 68871}$ & Hemoglobin subunit beta & 16 & 6.8 & 84 \\
\hline 24 & $\underline{\mathrm{P} 00738}$ & Haptoglobin & 43 & 6.1 & 40 \\
\hline 25 & $\underline{\mathrm{P} 08238}$ & Heat shock protein HSP 90-beta & 83 & 5.0 & 24 \\
\hline 26 & $\underline{\text { P07900 }}$ & Heat shock protein HSP 90-alpha & 85 & 4.9 & 18 \\
\hline 27 & $\underline{\mathrm{P} 01876}$ & Ig alpha- 1 chain $C$ region & 38 & 6.1 & 29 \\
\hline 28 & $\underline{\mathrm{P} 01857}$ & Ig gamma-1 chain $\mathrm{C}$ region & 36 & 8.5 & 28 \\
\hline 29 & $\underline{P 01859}$ & Ig gamma-2 chain $\mathrm{C}$ region & 36 & 7.7 & 26 \\
\hline 30 & $\underline{\mathrm{P} 19827}$ & $\begin{array}{l}\text { Inter-alpha-trypsin inhibitor heavy } \\
\text { chain }\end{array}$ & 71 & 6.3 & 17 \\
\hline 31 & $\underline{\mathrm{P} 13645}$ & Keratin, type I cytoskeletal 10 & 60 & 5.1 & 24 \\
\hline 32 & $\underline{\text { P35527 }}$ & Keratin, type I cytoskeletal 9 & 62 & 5.2 & 16 \\
\hline 33 & $\underline{\mathrm{P} 04264}$ & Keratin, type II cytoskeletal 1 & 66 & 8.2 & 26 \\
\hline 34 & $\underline{\mathrm{P} 01042}$ & Kininogen-1 & 70 & 6.2 & 22 \\
\hline 35 & $\underline{\mathrm{P} 00734}$ & Prothrombin & 65 & 5.2 & 50 \\
\hline 36 & $\underline{\mathrm{P} 02787}$ & Serotransferrin & 75 & 6.7 & 47 \\
\hline 37 & $\underline{\mathrm{P} 02766}$ & Transthyretin & 14 & 5.4 & 80 \\
\hline 38 & $\underline{\mathrm{P} 02774}$ & Vitamin D-binding protein & 51 & 5.2 & 53 \\
\hline 39 & $\underline{P 25311}$ & Zinc-alpha-2-glycoprotein & 32 & 5.6 & 22 \\
\hline
\end{tabular}

1 Swiss-Prot/TrEMBL accession line.

2 Swiss-Prot/TrEMBL description line.

${ }^{3}$ Theoretical protein mass.

${ }^{4}$ Theoretical protein isoelectric point.

${ }^{5}$ Number of amino acids present in at least one peptide over the number of amino acids of the protein.

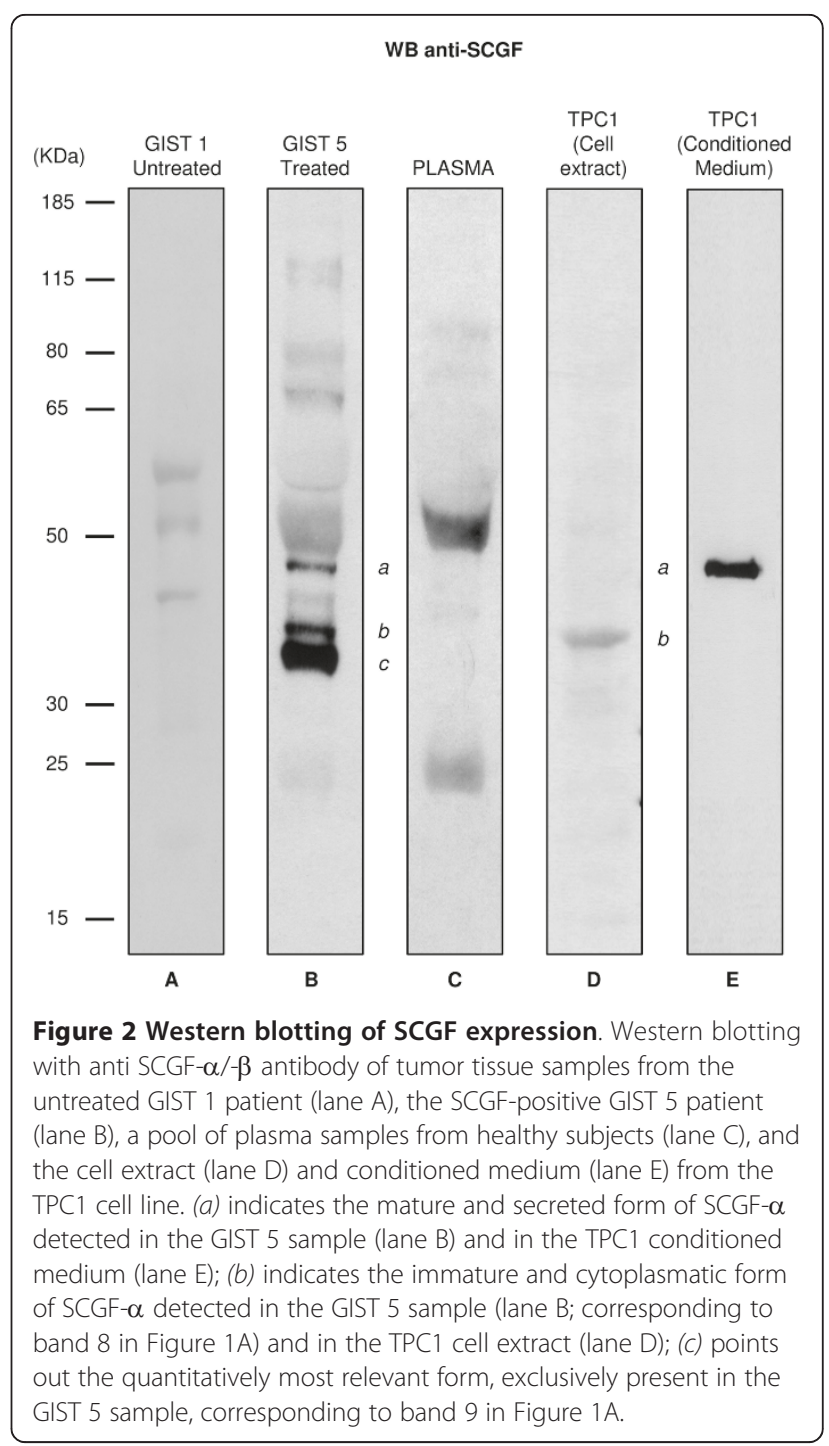

responsive tumoral areas that was absent in lysates from matched non-responsive or scarcely responsive areas (Figure 5A). These observations strongly support a relationship between SCGF positivity and low cellularity due to imatinib activity. In addition, we noted the presence of inflammatory cell infiltrate in the hematoxylin-eosin section of the responding area of GIST 6 (panels 2 and 3), of scattered lymphocytes in the hematoxylin-eosin section of the responding area of GIST 7 (panels 7 and 8), and of monocytes/macrophages in the hematoxylin-eosin section of the responding area of GIST 8 (panels 12 and 13). One SCGF-related signal was also detected by western blot in responding GISTs 14 and 16, but not in responding GIST 15 and non-responding GISTs 9-13 (Table 1 and Figure 5B).

SCGF is a secreted cytokine expressed in two distinct forms; SCGF- $\alpha$ is the full size form (323 amino acids, 


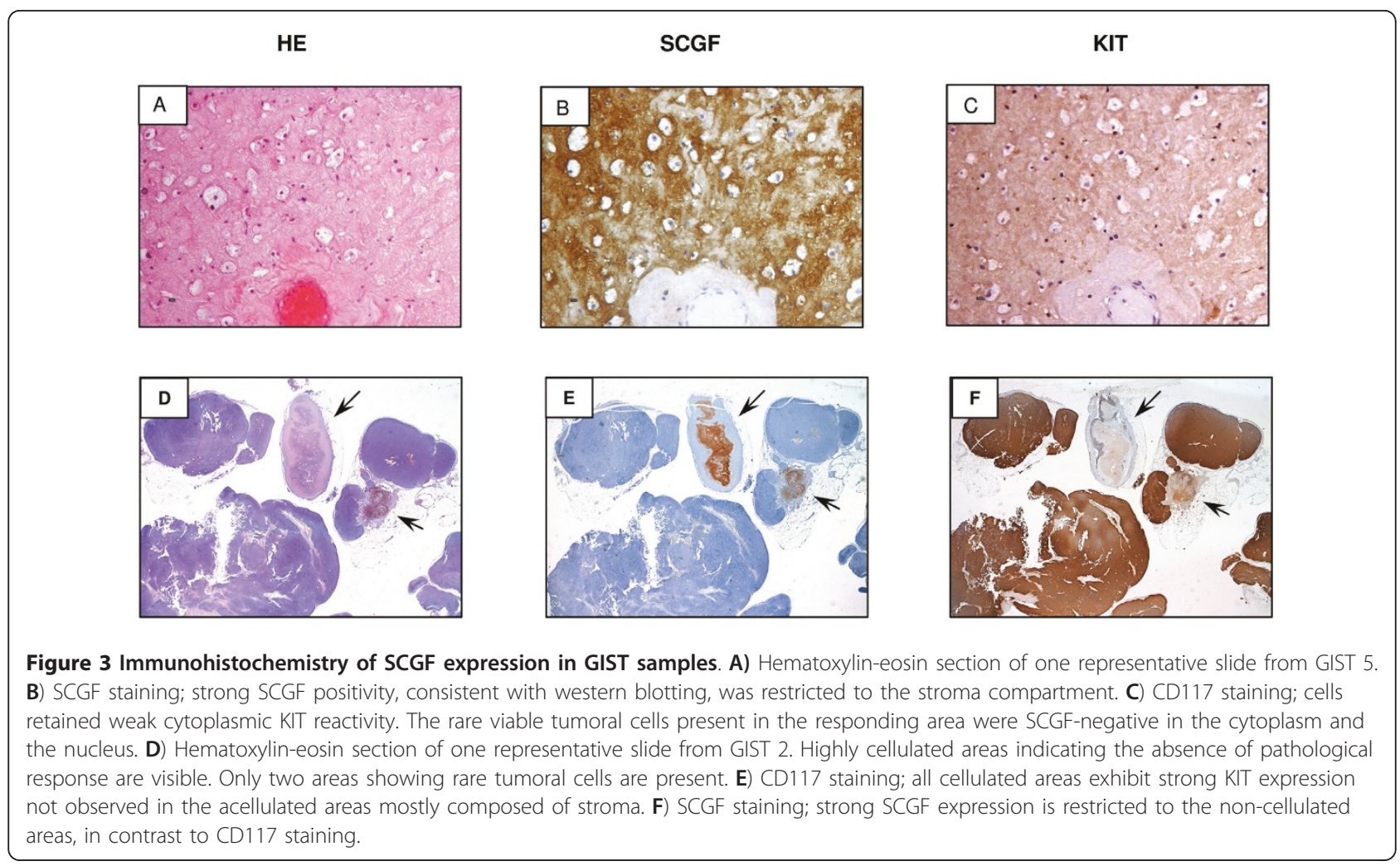

$35,695 \mathrm{Da})$, while SCGF- $\beta$ is the shorter form (245 amino acids, 26,902 $\mathrm{Da}$ ) characterized by a deletion within a conserved carbohydrate recognition domain [33]. These theoretical masses only partially explain the observed molecular weights in electrophoretic separations. The spectra from our MALDI-TOF-MS of tryptic peptides from two SCGF-positive bands (band 8 and 9 in Figure 1, lane E) were nearly identical in size and were attributed to the $\alpha$ form (lanes $G$ and $H$ in Figure 1A).

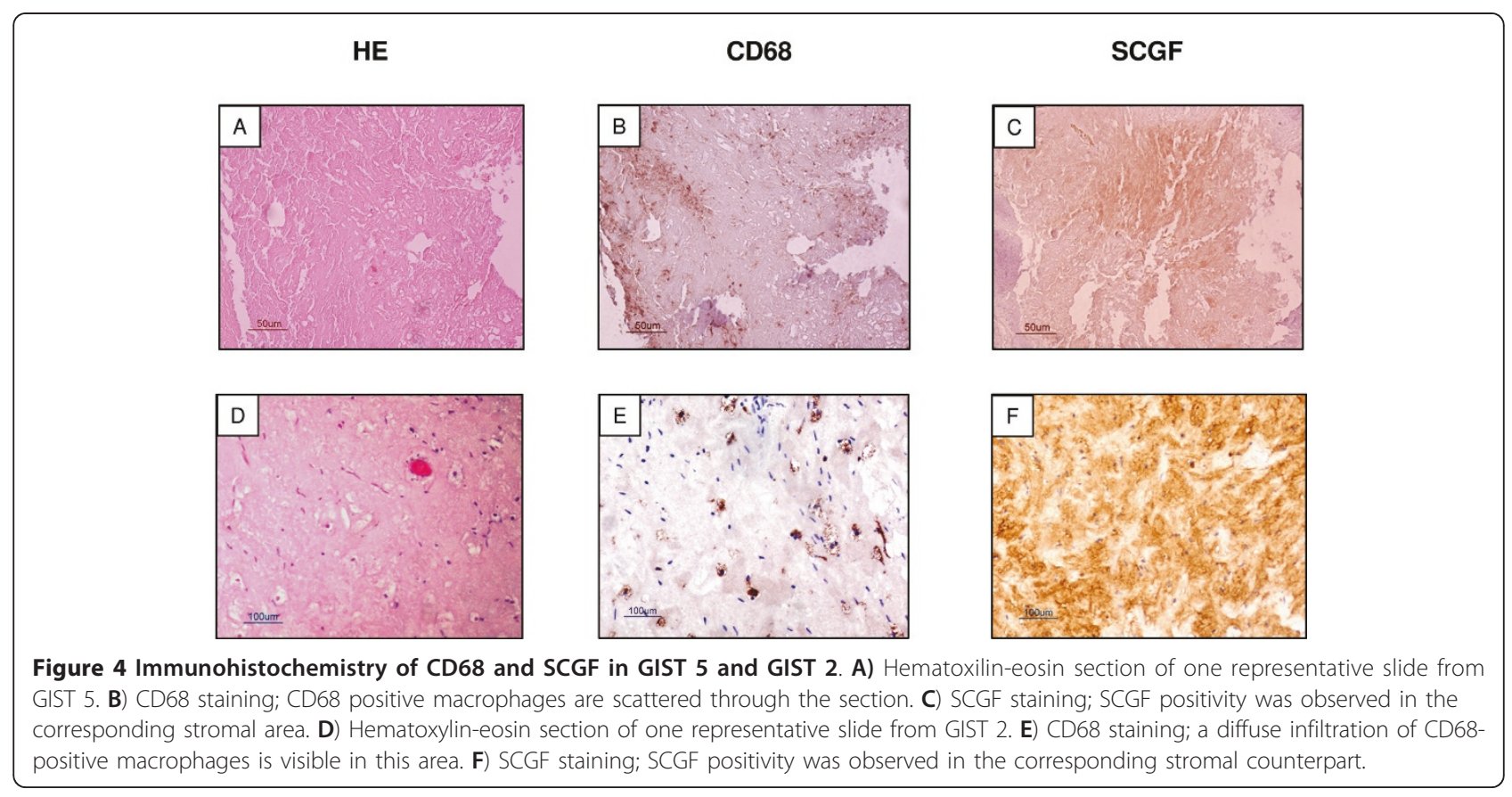




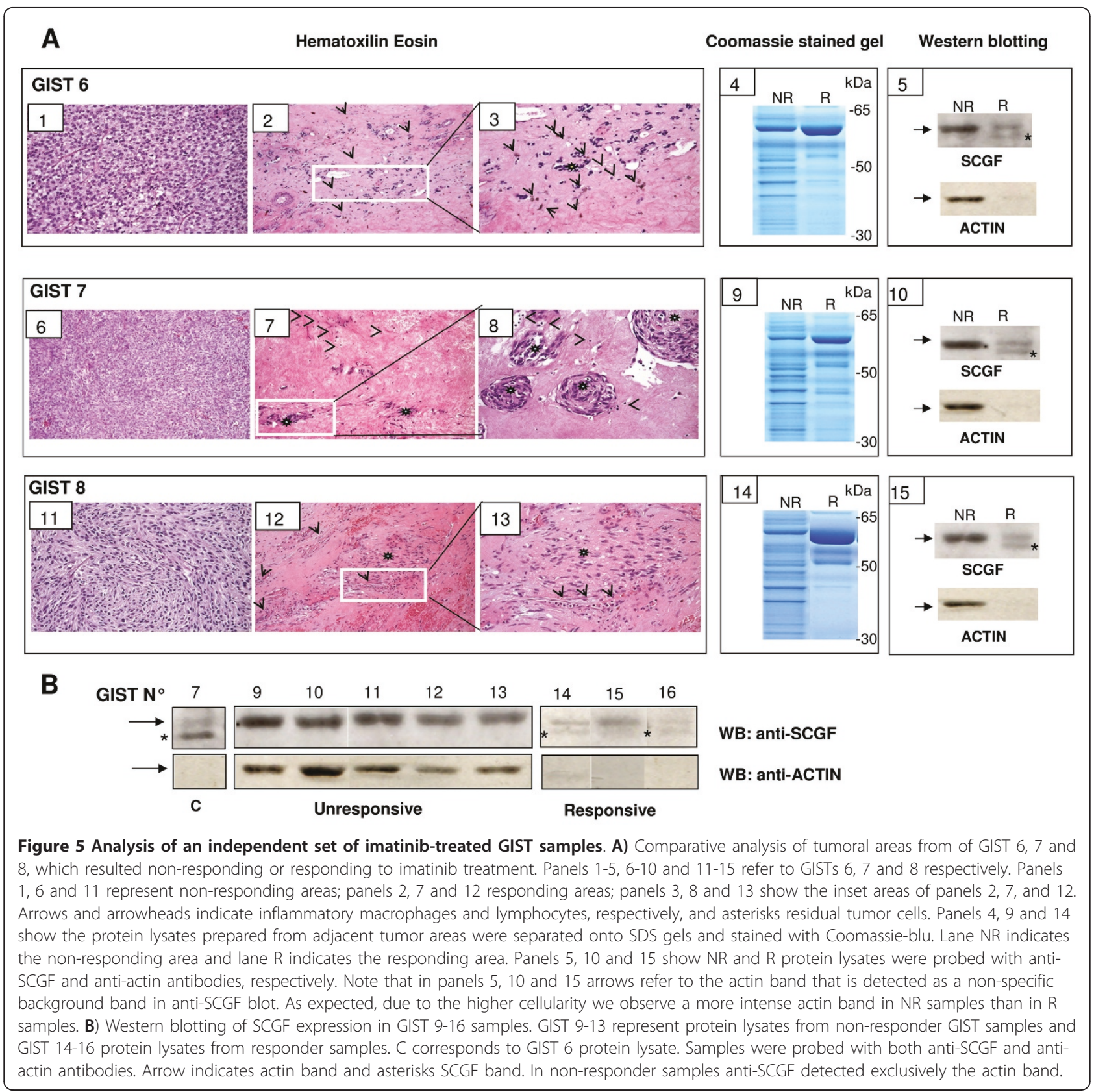

Since SCGF has been described as O-glycosylated and sulphated, we deglycosylated the GIST 5 lysate to determine the sizes of SCGF bands before and after digestion. The immunoreactive band with the highest molecular weight (band $a$ in Figure 6, lane 1) completely disappeared after deglycosylation; the intermediate band (band $b$ in Figure 6, lane 1) remained unmodified, and the lowest band (band $c$ in Figure 6, lane 1) exhibited an appreciable, apparently incomplete reduction in its molecular weight (band $d$ in Figure 6, lane 2). Isoform $a$ also occurred in conditioned medium (Figure 6, lane 4), as compared with isoforms expressed by the TPC1 cell line (Figure 6, lanes
3-5). Isoform $a$ was equivalent to the fully glycosylated and secreted form, while the low-molecular weight isoform in the cell extract (band $b$ in Figure 6, lanes 3 and 5) was equivalent to an immature, cytoplasmatic, unglycosylated form. Interestingly, we observed SCGF positivity for the isoforms corresponding to bands $a$ and $b$ in Figure 2, which were also observed in the conditioned medium (Figure 2, lane E) and in the cell extract (Figure 2, lane D) of the TPC1 cell line.

To further define the nature of SCGF isoforms expressed in the GIST 5 sample, we tested the possibility that the other form corresponded to isoform $\beta$. We 


\section{WB anti-SCGF}

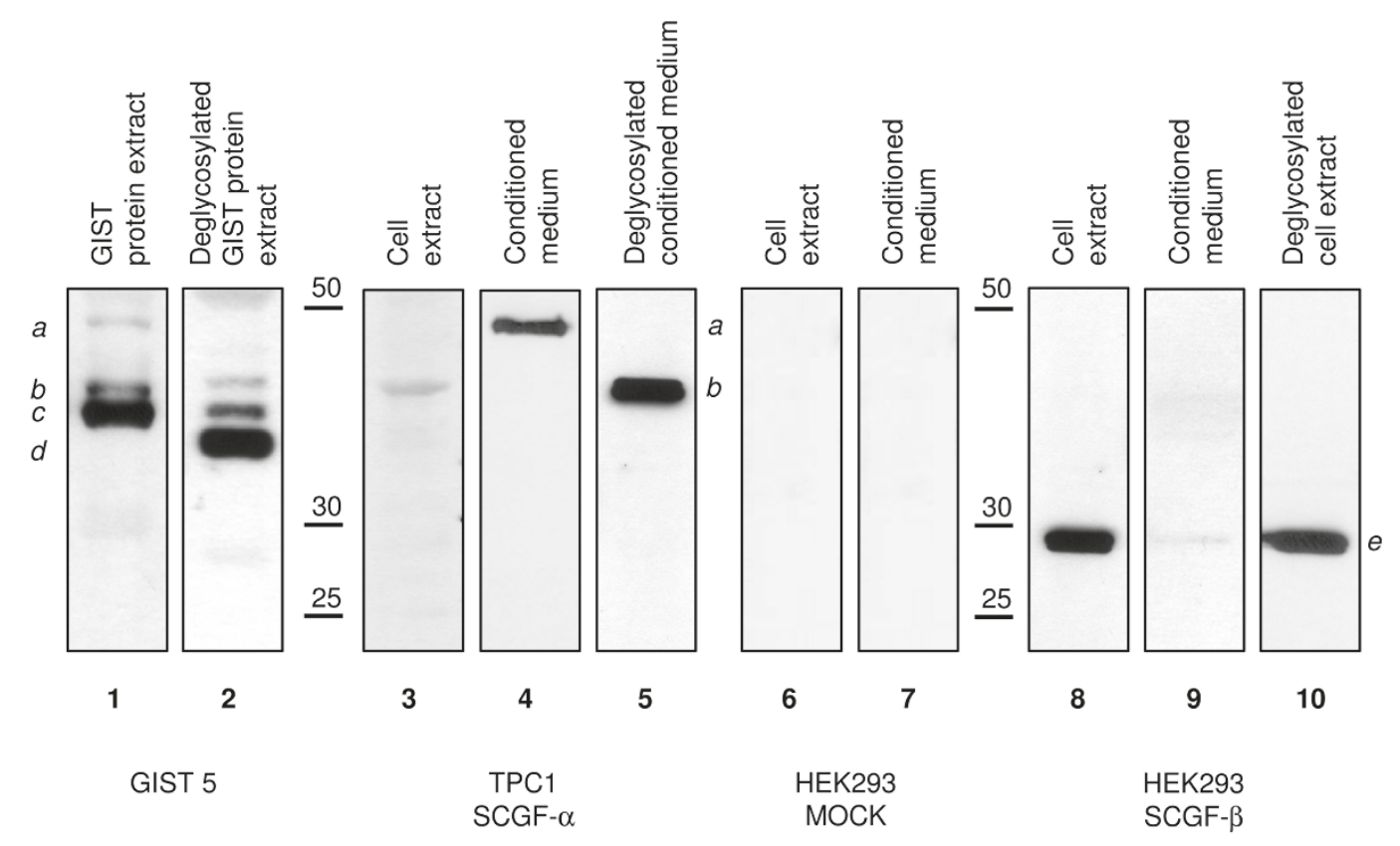

Figure 6 Western blotting of SCGF after deglycosylation. Western blotting with anti-SCGF- $\alpha /-\beta$ antibody. Lanes 1 and 2 compare SCGF patterns in the untreated (lane 1) and the deglycosylated (lane 2) protein extract of the GIST 5 sample. Lanes 3-5 contain a comparison of the cytoplasmatic (lane 3) and the secreted (lane 4) SCGF- $\alpha$ forms and the untreated (lane 4) and the deglycosylated secreted (lane 5) SCGF- $\alpha$ forms in the TPC1 cell line. Lanes 6 and 7 depict the expression of SCGF- $\alpha$ and $-\beta$ in the cell extract and conditioned medium of a mock HEK293 cell line (negative control). Lanes 8-10 reflect SCGF- $\beta$ expression in the cell extract (lane 8) and conditioned medium (lane 9) of the transfected HEK293 cell line; lanes 8 and 10 show the untreated and the deglycosylated SCGF- $\beta$ forms in the transfected HEK293 cell line extract. The mature and secreted forms of SCGF- $\alpha$ detected in the GIST 5 sample (lane 1) and the TPC1 conditioned medium (lane 4) are indicated by (a); (b) indicates an immature, cytoplasmatic, unglycosylated form of SCGF- $\alpha$ in the untreated (lane 1) and deglycosylated (lane 2) GIST 5 samples, and in the cell extract (lane 3) and conditioned medium of the TPC1 cell line after deglycosylation (lane 5); the form indicated by (c) was exclusively detected in the GIST 5 sample, was the quantitatively most relevant form in the untreated sample (lane 1), and was observed after deglycosylation (lane 2); (d) indicates the form exclusively detected and quantitatively most relevant in the deglycosylated GIST 5 sample (lane 2), corresponding to the protein backbone of SCGF- $\alpha(\sim 36 \mathrm{kDa})$; (e) indicates the form detected in the untreated (lane 8) and deglycosylated (lane 10) cell extract of the transfected HEK293 cell line, corresponding to the primary structure of SCGF- $\beta(\sim 27 \mathrm{kDa})$.

transfected the HEK293 cell line that scored negative for SCGF proteins (Figure 6, lanes 6 and 7) with SCGF- $\beta$ cDNA. Western blotting detected a protein with the size expected for the SCGF- $\beta$ backbone (Figure 6, lanes 8-10) that did not correspond to band $d$ of the GIST 5 sample (Figure 6, lane 2). Thus, we concluded that band $d$ was not the SCGF- $\beta$ form.

\section{Discussion}

Few studies have correlated clinical response with histological response in GISTs after prolonged imatinib treatment. However, it is widely recognized that clinical outcome in stable or partially responsive GIST patients does not seem to be influenced by the duration of imatinib treatment, the histological response, or the size of the tumor [18]. In this study, we analyzed the proteomic, histological, immunohistochemical, and clinical features of a small group of GISTs resected after prolonged imatinib treatment.

SCGF, a novel cytokine, exerts its action on primitive hematopoietic progenitor cells. In combination with other hematopoietic growth factors such as granulocyte-macrophage colony-stimulating factor and erythropoietin, SCGF stimulates the formation of erythroid and granulocyte/ macrophage colonies, although SCGF alone cannot induce colony formation [29]. Using a proteomic approach, we detected a large amount of SCGF in the protein extract of one imatinib-treated GIST sample (Figure 1). This sample also had a residual cell component of $<10 \%$ and was negative or very slightly positive for CD117 staining. Biochemical analyses revealed the presence of a small number of KIT receptors with very low activation (data not shown). In parallel, we found extensive SCGF positivity in the abundant stromal component, which appeared homogenous, 
hypodense, and eosinophilic. This observation was replicated in part of the progressive lesion of another treated GIST case in which we identified strong SCGF positivity exclusively in CD117-negative areas. Interestingly, SCGF expression occurred in the imatinib-affected areas of three GISTs that was not detected in the unaffected or scarcely affected areas of the same tumors; SCGF-positive bands were also identified in two out three responding tumors but were absent in tumors from five non-responder patients.

A study carried out on in vivo material demonstrated that SCGF is strongly expressed in bone marrow and only faintly in lymphoid organs; in bone marrow, SCGF is concentrated in the cytoplasm of immature neutrophils, but not in myeloblasts, mature neutrophils, or the extracellular bone marrow fluid [34]. Since immature neutrophils play a role in tumor-induced immuno-inflammatory responses, SCGF may impact mechanisms regulating these responses. These observations are consistent with RNA expression patterns in mouse and human protein-encoding transcriptomes [35] and are attributed as follows: high expression levels to CD34+ cells, low expression levels to CD33+ (myeloid) cells, cardiomyocytes, and smooth muscle cells, and very low expression levels to all other cell lines or tissues.

Hiraoka [36] recently demonstrated that leukemia cell lines require self-secreted SCGF for their proliferation in tumors, indicating a putative autocrine SCGF mechanism, and that loop blockage with neutralizing antibody prevents extracellular SCGF from inducing apoptosis. Levina et al. [37] demonstrated that the high tumorigenic and metastatic potentials of lung cancer stem cells correlated with superior production of angiogenic factors and growth factors involved in cell proliferation and angiogenesis, describing increased levels of SCGF, stromaderived factor $1 \alpha$, and SCF in tumors from cancer stem cells in association with the stem cell phenotype. Geneexpression profiles from 35 childhood acute lymphoblastic leukemia matched diagnosis/relapse pairs, as well as 60 uniformly treated children at relapse, indicated that SCGF is significantly overexpressed at relapse [38].

The presence of SCGF in the CD117-negative stromal compartment of imatinib-treated GISTs suggests that its expression is associated with the histological response of GISTs to imatinib therapy. Our RT-PCR investigation revealed that SCGF is not actively transcribed in GIST samples, and thus it is difficult to determine the possible sources of SCGF in these specimens. A recent study described a subgroup of GISTs surgically resected after neoadjuvant imatinib treatment that exhibited reduced numbers of tumor cells in the hypocellular myxohyaline stroma, with small numbers of scattered atypical nuclei and occasional stromal hemorrhages [39]. A separate investigation assessed a GIST case treated with imatinib therapy for four weeks in which most of the tumor cells were replaced by myxoid stroma and the remaining tumor cells did not appear to be actively dividing [40]. However, to date no study has reported data on SCGF in GIST samples.

In our study, SCGF appeared as part of the stromal GIST component and, in particular, as part of the eosinophilic proteinaceous matrix described as myxoid, collagenous, or hyaline. Our proteomics experiment uncovered high plasma-protein content in treated tumors, and immunohistochemistry revealed the SCGF positivity in CD117-negative and CD68-positive areas. These observations could link SCGF positivity with the imatinibinduced inflammatory response that elicits monocyte/ macrophage tissue migration, promoting scarring and removal of cell debris. CD68 positivity confirms macrophage infiltration, which may also explain the high level of C1q [41] in our GIST 5 proteomic analysis. Recent data support the hypothesis that induced type I maturation of dendritic cells is associated with a peak of SCGF production [1], supporting a pro-inflammatory role for this cytokine. It is therefore plausible that these are immunological reactions, and that liquidation of the dead tumor cells via macrophages leads to lesion shrinkage.

\section{Conclusions}

SCGF function may be related to the imatinib-induced inflammation response in responding GIST patients. Further studies are necessary to identify the receptor of this cytokine, to further clarify its origin, and to determine the reason for its accumulation in some imatinibtreated GISTs. These investigations may answer fundamental questions about the composition of the stromal matrix after imatinib therapy and identify proteins related to desirable tumor response/behavior.

\section{Additional material}

Additional file 1: Hematoxylin-eosin sections of representative slides from GIST 1, 3 and 4.

Additional file 2: Espression of SCGF RNA in GIST samples 3, 4 and 5.

\section{Acknowledgements}

This study was supported by grants from the Associazione Italiana per la Ricerca sul Cancro (AIRC, Milan, Italy) and Alleanza Contro il Cancro (ACC). We thank Ms. Mazzadi Cristina for secretarial assistance.

\section{Author details}

${ }^{1}$ Proteomics Laboratory, Department of Experimental Oncology and Molecular Medicine, Fondazione IRCCS Istituto Nazionale dei Tumori, Milan, Italy. ${ }^{2}$ Experimental Molecular Pathology, Department of Pathology, Fondazione IRCCS Istituto Nazionale dei Tumori, Milan, Italy. ${ }^{3}$ Department of Cancer Medicine, Fondazione IRCCS Istituto Nazionale dei Tumori, Milan, Italy. ${ }^{4}$ Unit of Immunotherapy of Human Tumors, Department of Experimental Oncology Fondazione IRCCS Istituto Nazionale dei Tumori, Milan, Italy. ${ }^{5}$ Department of Surgery, Fondazione IRCCS Istituto Nazionale dei 
Tumori, Milan, Italy. ${ }^{6}$ Scientific Directorate, Fondazione IRCCS Istituto Nazionale dei Tumori, Milan, Italy.

\section{Authors' contributions}

$L D V, F B$, and IB planned the study and drafted the manuscript; $F B, V H, A G$, $F M, E T, E F$ and MAP contributed to the design of the study and critically revised the manuscript; LDV, PM, FB, FM, Eva T, and EV performed western blotting and immunohistochemical experiments; SP contributed to data analysis. All the authors have read and approved the manuscript.

\section{Competing interests}

The authors declare that they have no competing interests.

Received: 11 May 2011 Accepted: 23 September 2011 Published: 23 September 2011

\section{References}

1. Gundacker NC, Haudek VJ, Wimmer H, Slany A, Griss J, Bochkov V, et al: Cytoplasmic Proteome and Secretome Profiles of Differently Stimulated Human Dendritic Cells. Journal of Proteome Research 2009, 8:2799-2811.

2. Dematteo RP, Lewis JJ, Leung D, Mudan SS, Woodruff JM, Brennan MF: Two hundred gastrointestinal stromal tumors: recurrence patterns and prognostic factors for survival. Ann Surg 2000, 231:51-58.

3. Joensuu H, Fletcher C, Dimitrijevic S, Silberman S, Roberts P, Demetri G: Management of malignant gastrointestinal stromal tumours. Lancet Oncol 2002, 3:655-664.

4. Nilsson B, Bumming P, Meis-Kindblom JM, Oden A, Dortok A, Gustavsson B, et al: Gastrointestinal stromal tumors: the incidence, prevalence, clinical course, and prognostication in the preimatinib mesylate era-a population-based study in western Sweden. Cancer 2005, 103:821-829.

5. Kindblom LG, Remotti HE, Aldenborg F, Meis-Kindblom JM: Gastrointestinal pacemaker cell tumor (GIPACT) - Gastrointestinal stromal tumors show phenotypic characteristics of the interstitial cells of Cajal. American Journal of Pathology 1998, 152:1259-1269.

6. Corless CL, Fletcher JA, Heinrich MC: Biology of gastrointestinal stromal tumors. J Clin Oncol 2004, 22:3813-3825.

7. Williams DE, Eisenman J, Baird A, Rauch C, Vanness K, March CJ, et al: Identification of A Ligand for the C-Kit Protooncogene. Cell 1990, 63:167-174.

8. Yarden Y, Kuang WJ, Yang-Feng T, Coussens L, Munemitsu S, Dull TJ, et al: Human proto-oncogene c-kit: a new cell surface receptor tyrosine kinase for an unidentified ligand. EMBO J 1987, 6:3341-3351.

9. Zsebo KM, Wypych J, McNiece IK, Lu HS, Smith KA, Karkare SB, et al: Identification, purification, and biological characterization of hematopoietic stem cell factor from buffalo rat liver-conditioned medium. Cell 1990, 63:195-201.

10. Theou-Anton N, Tabone S, Brouty-Boye D, Saffroy R, Ronnstrand L, Lemoine A, et al: Co expression of SCF and KIT in gastrointestinal stroma tumours (GISTs) suggests an autocrine/paracrine mechanism. $\mathrm{Br} J$ Cancer 2006, 94:1180-1185.

11. Miettinen M, Lasota J: KIT (CD117): a review on expression in normal and neoplastic tissues, and mutations and their clinicopathologic correlation. Appl Immunohistochem Mol Morphol 2005, 13:205-220.

12. Rubin BP, Heinrich MC, Corless CL: Gastrointestinal stromal tumour (vol 369, pg 1731, 2007). Lancet 2007, 370:388.

13. Verweij J, Casali PG, Zalcberg J, LeCesne A, Reichardt P, Blay JY, et al: Progression-free survival in gastrointestinal stromal tumours with highdose imatinib: randomised trial. Lancet 2004, 364:1127-1134.

14. van GM, Verweij J, Casali PG, Le CA, Hohenberger P, Ray-Coquard I, et al Initial and late resistance to imatinib in advanced gastrointestinal stromal tumors are predicted by different prognostic factors: a European Organisation for Research and Treatment of Cancer-Italian Sarcoma Group-Australasian Gastrointestinal Trials Group study. J Clin Oncol 2005, 23:5795-5804.

15. Scaife CL, Hunt KK, Patel SR, Benjamin RS, Burgess MA, Chen LL, et al: Is there a role for surgery in patients with "unresectable" cKIT+ gastrointestinal stromal tumors treated with imatinib mesylate? Am J Surg 2003, 186:665-669.

16. Choi $\mathrm{H}$ : Response evaluation of gastrointestinal stromal tumors. Oncologist 2008, 13:4-7
17. Miselli F, Casieri P, Negri T, Orsenigo M, Lagonigro MS, Gronchi A, et al: c-Kit/PDGFRA gene status alterations possibly related to primary imatinib resistance in gastrointestinal stromal tumors. Clinical Cancer Research 2007, 13:2369-2377.

18. Agaram NP, Besmer P, Wong GC, Guo TH, Socci ND, Maki RG, et al: Pathologic and molecular heterogeneity in imatinib-stable or imatinibresponsive gastrointestinal stromal tumors. Clinical Cancer Research 2007 13:170-181.

19. Duensing A, Medeiros F, McConarty B, Joseph NE, Panigrahy D, Singer S, et al: Mechanisms of oncogenic KIT signal transduction in primary gastrointestinal stromal tumors (GISTs). Oncogene 2004, 23:3999-4006.

20. Bauer S, Duensing A, Demetri GD, Fletcher JA: KIT oncogenic signaling mechanisms in imatinib-resistant gastrointestinal stromal tumor: $\mathrm{PI3}$ kinase/AKT is a crucial survival pathway. Oncogene 2007, 26:7560-7568.

21. McAuliffe JC, Hunt KK, Lazar AJ, Choi H, Qiao W, Thall P, et al: A randomized, phase II study of preoperative plus postoperative imatinib in GIST: evidence of rapid radiographic response and temporal induction of tumor cell apoptosis. Ann Surg Oncol 2009, 16:910-919.

22. Miselli F, Negri T, Gronchi A, Losa M, Conca E, Brich S, Fumagalli E, Fiore M, Casali PG, Pierotti MA, et al: Is autophagy rather than apoptosis the regression driver in imatinib-treated gastrointestinal stromal tumors? Transl Oncol 2008, 1:177-186.

23. Klionsky DJ, Emr SD: Autophagy as a regulated pathway of cellular degradation. Science 2000, 290:1717-1721

24. Casali PG, Blay JY: Gastrointestinal stromal tumours: ESMO Clinical Practice Guidelines for diagnosis, treatment and follow-up. Annals of Oncology 2010, 21:v98-v102.

25. Gorla L, Mondellini P, Cuccuru G, Micciche F, Cassinelli G, Cremona M, et al: Proteomics Study of Medullary Thyroid Carcinomas Expressing RET Germ-Line Mutations: Identification of New Signaling Elements. Molecular Carcinogenesis 2009, 48:220-231.

26. Michel PE, Crettaz D, Morier P, Heller M, Gallot D, Tissot JD, et al: Proteome analysis of human plasma and amniotic fluid by Off-Gel (TM) isoelectric focusing followed by nano-LC-MS/MS. Electrophoresis 2006, 27:1169-1181.

27. Perrone F, Tamborini E, Dagrada GP, Colombo F, Bonadiman L, Albertini V, et al: 9p21 Locus analysis in high-risk gastrointestinal stromal tumors characterized for c-kit and platelet-derived growth factor receptor alpha gene alterations. Cancer 2005, 104:159-169.

28. Mercalli E, Ghizzoni S, Arighi E, Alberti L, Sangregorio R, Radice MT, et al: Key role of Shc signaling in the transforming pathway triggered by Ret/ ptc2 oncoprotein. Oncogene 2001, 20:3475-3485.

29. Hiraoka A, Sugimura A, Seki T, Nagasawa T, Ohta N, Shimonishi M, et al: Cloning, expression, and characterization of a cDNA encoding a novel human growth factor for primitive hematopoietic progenitor cells. Proceedings of the National Academy of Sciences of the United States of America 1997, 94:7577-7582.

30. Kojouharova M, Reid K, Gadjeva M: New insights into the molecular mechanisms of classical complement activation. Molecular Immunology 2010, 47:2154-2160

31. Ito C, Sato H, Ando K, Watanabe S, Yoshiba F, Kishi K, et al: Serum stem cell growth factor for monitoring hematopoietic recovery following stem cell transplantation. Bone Marrow Transplantation 2003, 32:391-398.

32. Hiraoka A, Yano KK, Kagami N, Takeshige K, Mio H, Anazawa H, et al: Stem cell growth factor: in situ hybridization analysis on the gene expression, molecular characterization and in vitro proliferative activity of a recombinant preparation on primitive hematopoietic progenitor cells. Hematol J 2001, 2:307-315.

33. Mio H, Kagami N, Yokokawa S, Kawai H, Nakagawa S, Takeuchi K, et al: Isolation and characterization of a cDNA for human, mouse, and rat fulllength stem cell growth factor, a new member of C-type lectin superfamily. Biochemical and Biophysical Research Communications 1998 249:124-130

34. Perrin C, Bayle J, Bannwarth S, Michiels JF, Heudier P, Lefebvre JC, et al: Expression of LSLCL, a new C-type lectin, is closely restricted, in bone marrow, to immature neutrophils. C R Acad Sci III 2001, 324:1125-1132.

35. Su Al, Wiltshire T, Batalov S, Lapp H, Ching KA, Block D, et al: A gene atlas of the mouse and human protein-encoding transcriptomes. Proc Natl Acad Sci USA 2004, 101:6062-6067.

36. Hiraoka A: Leukemia cell lines require self-secreted stem cell growth factor (SCGF) for their proliferation. Leukemia Research 2008, 32:1623-1625. 
37. Levina V, Marrangoni AM, DeMarco R, Gorelik E, Lokshin AE: Drug-selected human lung cancer stem cells: cytokine network, tumorigenic and metastatic properties. PLoS One 2008, 3:e3077.

38. Bhojwani D, Kang HN, Moskowitz NP, Min DJ, Lee H, Potter JW, et al: Biologic pathways associated with relapse in childhood acute lymphoblastic leukemia: a Children's Oncology Group study. Blood 2006, 108:711-717.

39. Demetri GD, von Mehren M, Blanke CD, Van den Abbeele AD, Eisenberg B, Roberts PJ, et al: Efficacy and safety of imatinib mesylate in advanced gastrointestinal stromal tumors. New England Journal of Medicine 2002, 347:472-480.

40. Joensuu H, Dimitrijevic S: Tyrosine kinase inhibitor imatinib (STI571) as an anticancer agent for solid tumours. Annals of Medicine 2001, 33:451-455.

41. Sontheimer RD, Racila E, Racila DM: C1q: its functions within the innate and adaptive immune responses and its role in lupus autoimmunity. $J$ Invest Dermatol 2005, 125:14-23.

doi:10.1186/1479-5876-9-158

Cite this article as: Da Riva et al:: Proteomic detection of a large

amount of SCGF $\alpha$ in the stroma of GISTs after imatinib therapy. Journal of Translational Medicine 2011 9:158.

\section{Submit your next manuscript to BioMed Central} and take full advantage of:

- Convenient online submission

- Thorough peer review

- No space constraints or color figure charges

- Immediate publication on acceptance

- Inclusion in PubMed, CAS, Scopus and Google Scholar

- Research which is freely available for redistribution

Submit your manuscript at www.biomedcentral.com/submit 